\title{
IMPLICATIONS OF THE CURRENT TREND IN MORTGAGE VALUATION PRACTICE IN NIGERIA
}

\author{
Bioye Tajudeen ALUKO \\ Department of Estate Management, Obafemi Awolowo University, Ile-Ife, Nigeria \\ E-mail: btaluko@oauife.edu.ng
}

Received 23 March 2006; accepted 24 January 2007

\begin{abstract}
The emerging concern on the reliability of property valuations coupled with the attendant consequences of growing number of distressed banks in Nigeria necessitate this study. Therefore, the study examined the mortgage valuation process including sources of valuation instructions, bases and methods being adopted and their implications on lending decisions and valuation profession in the study area. To accomplish the study, questionnaires were randomly administered on samples of estate surveying and valuation firms and lending institutions respectively in Lagos Metropolis. The data emanating therefrom were analysed using frequency distributions, ranking mean and relative important index ranking. The study, prima facie, established that mortgage valuation has been an important input in lending decisions. It further showed the implications of the blind adoption of the cost approach, inconsistency amongst valuers and non - inclusion of insurance valuation in the mortgage valuation process.
\end{abstract}

KEYWORDS: Mortgage valuation; Implications; Lending institutions; Estate surveying and valuation firms; Distressed banks

\section{INTRODUCTION}

The cyclical downturn in the banking industry and property market has exposed the inability of estate surveyors and valuers to predict accurately valuation estimates and, the lack of consistency in valuations have been strongly criticized by clients of valuers in $\mathrm{Ni}$ geria. It is widely recognized that the banking system of any country plays a crucial role in the economic development efforts of such a country, which is why banks have been referred to as the engine of growth of an economy. It follows that when the banking system is distressed, the economy is bound to be distressed and vice-versa.
The number of distressed banking institutions soon increased from the 7 reported at the inception of the Nigeria Deport Insurance Corporation (NDIC) in 1988 to 8 in 1989 , then 9 in 1990, 15 in 1991, 16 in 1992, 38 in 1993, 55 in 1994, 60 in 1995 and 35 in 2002. Also, a joint Central Bank of Nigeria (CBN)/NDIC study in 1996 on distressed banks confirmed what regulators had all along suspected: that the distressed was caused by very large volumes of non-performing loan assets, insider abuses, frauds and forgeries. Loans and other forms of credit extensions to business and individual customers constitute traditional functions of banks. In the process of credit extension, fraud or negligence may occur at any

International Journal of Strategic Property Management

ISSN 1648-715X print / ISSN 1648-9179 online (C) 2007 Vilnius Gediminas Technical University

http://www.ijspm.vgtu.lt 
stage from the first interaction between the customer and the bank to the final payment of the loan. Fraud is proven when it can be shown that a false representation has been made, either knowingly or without belief in its truth or recklessly not caring whether it is true or false (Gronow, 1992). This is perhaps the risk with the largest loss to Nigerian bankers. It is in recognition of the prevalence and magnitude of these losses that banks are required to make adequate provision for bad and doubtful debts; and, also provides secured lending.

Credit institutions lent considerable sums of money to actors on the real estate market and property valuations were one important part of the material that these decisions were based on (Adair, Downie, McGreal and Vos, 1996). Thus, the original reason for providing a valuation for mortgage purposes was to prevent, or at least restrict, the misrepresentation of asset values, as a means of perpetuating fraud, avoiding blame or concealing losses (Gronow, 1992). Therefore, it is important in loan underwriting to known the degree by which the asset value exceeds the loan in providing the margin of asset cover or the loanto-value ratio. The lender needs to know the portion should the borrower default and have an idea of the amount that the sale of the property asset would realize were the receiver to sell the asset (Lovell and French, 1995). The ability of a bank to sustain credit risk in its loans and advances depend on the quality of mortgage valuations prepared by estate surveyors and valuers. The quality of any valuation depends on the data input, assumptions, valuation/pricing methodologies and the judgment exercised by valuers in the valuation process (Ordway and Bell, 1984; Aluko, 1999a). And, the choice of a valuer can also introduce undue influence into mortgage valuation outcome (Gronow, 1992; Crosby, Lavers and Foster, 2001). The quality of information available and the degree of subjectivity to which a method is exposed influence the reliability of valuations. Against the foregoing, there is considerable skepticism about the ability of the Nigerian Valuers, both within the professional and academic communities including users of valuations, to come up with reliable valuation estimates (Ogunba and Ajayi, 1998; Aluko, 2000) This study, therefore, intends to examine the bases, methods and procedure (including sources pf briefs) of mortgage valuation in the county with a view to improving their quality. Consequently, the paper is structured into six sections. The next section examines the concept of mortgage valuation. Also, while section three explains the methodology adopted in this study, section four deals with the mortgage valuation practice in the country. In addition, sections five and the final one will examine the implications of current practice and some conclusions and recommendations emanating therefrom respectively.

\section{CONCEPTUAL FRAMEWORK}

A mortgage is the giving of an interest in land or property as security for the repayment of a loan, the borrower having the right to recover the title to the real property when the loan is repaid. In lending decisions, the person - natural or legal, at a critical or disadvantaged portion should there be a default in the repayment of the loan is the mortgage or lender. The valuation must be able to expose the risks inherent in the mortgage investment and protect those who invest in them (Aluko, 1998). Nonetheless, the valuations to be carried out depend on the remedies that are available to a mortgagee or lender. These remedies are to (see, for example, Elias, 1962; Tobi, 1992; Aluko, 2001):

- take possession of the income of the property personally,

- appoint a receiver of the income of the property,

- apply to the court for a foreclosure order or for an order of sale, and,

- sell under the implied power of sale, particularly for a legal mortgage.

Whether a lender takes actual possession or appoints a receiver of rent, only the annual worth of the property or its rental value is being enjoyed. Likewise, with a foreclosure order or a sale out of court, capital valuation of 
the collateral security will be required. Thus, the capital and rental valuations are sine qua non to any decision on loan advance. This is because in the event of a default, at a time when it is undesirable to sell, the lender may enter into possession (by (her) himself or by a receiver) of the income, and use the margin of income to payoff a portion of the loan, until the amount outstanding has been reduced to a sum which can be realized in a sale. On the other hand, it is equally evident that the taking of possession, or the appointment of a receiver, will not provide an adequate remedy for the lender if the net income from the property used as collateral is insufficient to meet the interest on the loan (Aluko, 1999b). The valuer must value a property used as security on the same principle as for sale, since, the lender in order to realize the security can take advantage of the power of sale. This will assist credit institutions to determine how much they can safely or prudently lend.

\subsection{Bases of valuation}

Central to the above is the fact that property must be assumed to have been sold within reasonable period (with contracts unconditionally completed) for cash consideration at the date of valuation. The open market value (OMV) is therefore an indication of the assumed best price or basis at which the sale might take place. This is usually a spread or a range rather than spot or single value because of level of uncertainties in the property market; although, banks may prefer a single figure of value estimate to be reported by valuers (Lovell and French, 1995; Aluko, 2000). Besides, realization of collateral security can mean foreclosure and forced sale as valuers must err on the side of safety when making the valuation for mortgage purposes. It is likely that, if power of sale has to be exercised, it will be within a limited period and at a time when conditions are unfavorable. This requires a forced sale value in mortgage valuation and, it is defined in the Statements of Asset Valuation Practices (SAVP) in paragraph 2:4 and the property valuation standards by NIESV (1985) as "the open market value with the proviso that the vendor has imposed a time limit for completion which cannot be regarded as a "reasonable period". With this proviso, the value will be more akin to the one obtained by auction. However, a well advertised auction sale may approximate an open market value. The forced sale value will offer lenders protection against risks associated with recoupment of loan advances. Thus, the open market value will establish the upper limit, above which, the lender should not exceed in advancing a loan, while the forced sale value represents the lower limit. It will also afford the lender the opportunity to evaluate the potential profitability and security of the mortgage investment.

Again, market valuation provides estimate of a price achievable in market condition which pre-date the client's exposure to risk by investment in the property. There is some appeal, especially in the UK, in a valuation, which informs a prospective lender, or owner, of the price likely to be obtainable in the market conditions, which follow rather than precede the decision to invest (Gallimore, 1996). Valuation is a snapshot in time and offers no guarantee that the price paid is achievable again in the future. In the UK, in 1994, a committee set up by the Royal Institution of Chartered Surveyors (RICS) (1990), under the chairmanship of Michael Mallinson, mooted the idea of a 'stable value' with the introduction of Estimated Realization Price (ERP) and Estimated Restricted Realization Price (ERRP) for loan security valuation. The new concepts moves the marketing period, as assumed in OMV, from prior to the valuation date to a reasonable period running from it, the duration of the marketing period being determined by the valuer (Stork and Humphries, 1996). The concepts, although, not well accepted in the UK, are not known in the Nigerian valuation practice.

In addition to the above, it has been asserted by Aluko (2000) that if the mortgaged property includes buildings, it should be fully insured, and to that effect included in a mortgage deed and the mortgagor should keep the 
policy in being. Also, upon the discharge of the loan, it is expected that insurance company or insurer will re-transfer the policy to the mortgagor. Perhaps, this arrangement is to help minimize the risks inherent in real estate investment, mortgage inclusive. This is because an insurance policy is a social arrangement which provides financial compensation for the effect of misfortune which, may, probably, occur during the loan period. Tacitly, it shows that insurance valuation is also an integral part of mortgage valuation. There are too known bases of insurance valuation: reinstatement with new, and indemnity, since the essence of any insurance policy is to return the owners of property to their original position as if nothing had happened, in case of any incident (Sachs, 1985; Rees, 1988; Aluko, 1989; 1993). Reinstatement value is the cost of reproducing or replacing a mortgage building new while indemnity value is only appropriate, where the state of the building is to be considered and, where rebuilding after loss is not feasible.

It can be deduced from the above that the valuation of a property for mortgage will require auction sale or private treaty valuation as well as insurance valuation. Thus, the following bases of valuation should be considered where a loan is to be advanced: open market value, forced sale value, reinstatement (with new) value and indemnity value.

\subsection{Methods of valuation}

In arriving at the capital and rental value of a mortgaged property there are three approaches to value: cost, market comparison and investment or income capitalization methods, which appear dominant in the literature. (Marchitelli, 1992; Oetzel, 1993; Mason, 1993; Rodgers, 1994; Baum, Mackmin and Nunnington, 1997). The cost or contractor's method is based on the understanding that market participants relate value to cost. It is used to value properties that seldom change hands in the property market. It should be noted that besides giving effect to individual ideas, cost approach may not be appropriate since mortgage is an investment in the open market. However, it gives the most reliable value in the case of insurance valuation (Mason, 1993).

Also, the market comparison approach has been recommended as the most appropriate where there has been a number of similar properties sold or rented in the subject property's market areas, and with transactions which have taken place in the recent pass (Millington, 1988; Rodgers, 1994; Hansz, 2004). While the method may work well for assessing the capital and rental value of collateral, adopting this approach for a forced sale valuation is usually more difficult. This is also true of properties being valued for auction sale. First, it is difficult to get comparable evidence of distressed properties, although, those of auction transaction, will of course, be available. Nevertheless, because properties are individual and an auction achieves a sale on a given day, the value of a particular property can often be due merely to the whim of a particular investor (Manley, 1993).

Furthermore, the investment (income capitalization) method is used for valuing mortgaged properties since they are income producing investments. This approach is based on the principle that annual value and capital value are related to each other and, that given the income (annual value) a property produces, the capital value can be found. Variants of this method have been developed over the years as discounted cash flow techniques, real value approach, rational approach and equivalent yield method (Wood, 1972; Trott, 1980; 1986; Baum, 1986; Crosby, 1985; 1991). These new methods, unlike the traditional techniques, are not in use in the country (Aluko, 2000). Thus, in this research, the adoption of the conventional techniques, already discussed above, for mortgage valuation will be examined.

\subsection{Information content of mortgage valuation report}

Valuations are a function of information. The better the information set, the better the valuation. Valuation report is a way of convey- 
ing the information to the client who commissioned the report. It must, therefore, meet the needs of the client as well as uphold the standards set, for such valuation, in the profession (Aluko, 2000). In certain situations, the form of the mortgage valuation report should have been settled with the client, at the outset, at the time of instructions. No standard form of report in suitable for all occasions, but generally it should cover the matters set out and explained above including any other specific requirements of the client. It also covers both the intrinsic and extrinsic characteristics of the subject property to assist lenders evaluate its suitability of a loan facility. Patterned along Baum et al., (2001), Crosby et al., (1997) and Aluko (2000) this paper will compare the views of both the estate surveying and valuation companies and lending institutions on the relevance of the following information in a mortgage valuation reports: Date of valuation, the location of the property, purpose of valuation, type of interest valued, town planning and zoning details, physical description of property (including accommodation details), sources of data basis of valuation, method(s) of valuation used, opinion of value, the state of the economy, exclusion classes (non-publication of information or non-reliance on the report by a third party).

\subsection{Sources of valuation instruction}

Fraudulent practices have regularly occurred and, in numerous instances, the source of valuation instruction has been the vehicle for such fraud (Cleary, 1965; Gronow, 1992; Hansz and Diaz, 2001; Mokrane, 2002). In the country to- day, valuers are appointed to execute mortgage valuation assignments through the following sources; panel of valuers on retainership by the bank, independent valuer selected from the list prepared by the profession, the in-house valuer (staff) of the bank and, borrowers' valuers (Aluko, 1999b). Conflicts of interest can arise in mortgage valuation with the appointment of valuers. Therefore, it is important that a valuer is selected by the lender and not by the borrower, irrespective of the identity of the valuer, he/she cannot provide the best independent, unbiased advice if their relationship started out with the originator (borrower) (Stork and Humphries, 1996).

\section{RESEARCH METHODOLOGY}

The study population for the research are the estate surveying and valuation firms and lending institutions in the Metropolitan Lagos, Nigeria. Metropolitan Lagos is the economic nerve-centre of the country and, currently house most of the nation's head offices and branches of the estate surveying and valuation companies as well as the lending institutions. The study adopted a survey method with a sampling size of 59 out of 146 estate surveying firms in active operation in a total population of 239 . On the other hand, 42 out of 89 banks comprising of commercial and merchant banks in operation in the study area were considered (see Table 1). The sampling frames were based on the directories $(1994-2003)$ of The Nigerian Institution of Estate Surveyors and Valuers and the NDIC Annual Report and Statement of Accounts (1991-2003).

Table 1. Sampling frame and size

\begin{tabular}{llll}
\hline Target population & Total population & $\begin{array}{l}\text { Number in active } \\
\text { operation }\end{array}$ & Sampling size \\
\hline Estate surveying and valuation firms & 239 & 146 & 59 \\
Lending institutions & 107 & 89 & 42 \\
\hline
\end{tabular}

Source: Directories of The Nigerian Institution of Estate Surveyors and Valuers (1994-2003) and NDIC Annual Report and Statement of Accounts (19912003). 
Questionnaires were administered on them to elicit information on the bases and methods of mortgage valuation, sources of valuation instruction and information contents of mortgage valuation reports.

While managers in charge of loan advances and recovery completed questionnaires meant for banks, registered estate surveyors and valuers including principal partners, heads of valuation department and principal partners assisted with questionnaire administration for the respondent valuation firms. From Table 2 mortgage valuation represents a significant functions of the firms sampled and, by Table 3 , all the respondent practicing firms in the study area are well represented in the sample as $18.6 \%, 30.5 \%, 22 \%, 18.6 \%$ and $10.3 \%$ had been in practice for between $1-5$, $6-10,11-15,16-20$ and above 20 years respectively.

On the other hand, all the lending institutions sampled started operations before 1985 and all have their heads and branch offices in Lagos metropolis and in all the states of the federation. They are also all involved (100\% - see Table 4) in making loan advances to customers on request. This observation is not unexpected given that businessmen must diversify risks and that lending institutions can only make profit through credit creation.

Table 2. Importance of mortgage valuations to respondent estate surveying and valuation firms

\begin{tabular}{llll}
\hline Options & $\begin{array}{l}\text { Relative } \\
\text { frequency }\end{array}$ & $\begin{array}{l}\text { Absolute } \\
\text { frequency }\end{array}$ & $\begin{array}{l}\text { Cumulative } \\
\text { frequency }(\%)\end{array}$ \\
\hline Of very great importance & 47 & 79.7 & 79.7 \\
Of great importance & 10 & 16.9 & 96.6 \\
Of some importance & 2 & 3.4 & 100.0 \\
Of no importance & - & - & - \\
Total & 59 & 100.0 & - \\
\hline
\end{tabular}

Source: Field Survey and Analysis (2004)

Table 3. Year of Establishment of Valuation Firms

\begin{tabular}{llll}
\hline Age & $\begin{array}{l}\text { Relative } \\
\text { frequency }\end{array}$ & $\begin{array}{l}\text { Absolute } \\
\text { frequency }\end{array}$ & $\begin{array}{l}\text { Cumulative } \\
\text { frequency }(\%)\end{array}$ \\
\hline Between $1-5$ & 11 & 18.6 & 18.6 \\
Between $6-10$ & 18 & 30.5 & 49.1 \\
Between $11-15$ & 13 & 22.0 & 71.1 \\
Between $16-20$ & 11 & 18.6 & 89.7 \\
Above 20 & 6 & 10.3 & 100.0 \\
Total & 59 & 100.0 & - \\
\hline
\end{tabular}

Source: Field Survey and Analysis (2004)

Table 4. Involvement of lending institutions in loan advances

\begin{tabular}{llll}
\hline Options & $\begin{array}{l}\text { Relative } \\
\text { frequency }\end{array}$ & $\begin{array}{l}\text { Absolute } \\
\text { frequency }\end{array}$ & $\begin{array}{l}\text { Cumulative } \\
\text { frequency }(\%)\end{array}$ \\
\hline Yes & 42 & 100 & 100 \\
No & - & - & - \\
Total & 42 & 100 & 100 \\
\hline
\end{tabular}

Source: Field Survey and Analysis (2004) 
The data emanating from the survey above were analysed using frequency distributions and percentages, ranking and relative Importance index methods. They were employed to resolve issues bordering on the bases and methods of mortgage valuation, sources of valuation instruction as well as test the preferences of the respondent samples of valuation firms and lending institutions regarding the information contents of mortgage valuation reports in the study area.

\section{MORTGAGE VALUATION PRACTICE}

The views of the estate surveying and valuation firms and lending institutions were sought on mortgage valuation process and some factors including bases, methods, sources of valuation instruction and information con- tents of reports that could affect reliability of mortgage valuations. The results are provided as follows.

\subsection{Basis of valuation}

This is considered a very important determinant of mortgage value. Table 5 shows that majority of respondents firms, representing $96.6 \%$ and $57.6 \%$, considered open market value and forced sale value respectively as the appropriate bases of mortgage valuation. However, a significant number of the respondent firms (42.4\%) disagreed, particularly; with the view held by Lovell and French, (1995) that forced sale value is a basis of mortgage value. They supported this contention with the fact that in a case of default, despite the intervening period, the collateral ought to be revalued

Table 5. Multivariate analysis of assessment of valuation firm's views on mortgage valuation process

\begin{tabular}{|c|c|c|c|c|c|c|}
\hline S/No & Items & $\begin{array}{l}\text { Strongly } \\
\text { agree }\end{array}$ & $\begin{array}{l}\text { Somewhat } \\
\text { agree }\end{array}$ & $\begin{array}{l}\text { Somewhat } \\
\text { disagree }\end{array}$ & $\begin{array}{l}\text { Strongly } \\
\text { disagree }\end{array}$ & Total \\
\hline $\mathrm{a}$ & $\begin{array}{l}\text { Appropriate basis for } \\
\text { inclusion in mortgage } \\
\text { valuation }\end{array}$ & & & & & \\
\hline $\mathrm{i}$ & open market value & $39(66.1)$ & $18(30.5)$ & - & $2(3.4)$ & $59(100)$ \\
\hline ii & forced sale value & $34(57.6)$ & - & 7 (11.9) & $18(30.5)$ & $59(100)$ \\
\hline iii & re-instatement value & $2(3.4)$ & $1(1.7)$ & 7 (11.9) & $49(83.0)$ & $59(100)$ \\
\hline iv & indemnity value & $2(3.4)$ & $3(5.1)$ & $4(6.8)$ & $50(84.7)$ & $59(100)$ \\
\hline $\mathrm{b}$ & $\begin{array}{l}\text { Inclusion of insurance value } \\
\text { in the valuation report }\end{array}$ & $7(11.9)$ & $17(28.8)$ & $10(16.9)$ & $25(42.4)$ & $59(100)$ \\
\hline c & $\begin{array}{l}\text { Cost or contractor's method } \\
\text { as the most frequently } \\
\text { employed for mortgage } \\
\text { valuation in practice }\end{array}$ & $29(49.2)$ & $11(18.6)$ & $8(13.6)$ & $11(18.6)$ & $59(100)$ \\
\hline $\mathrm{d}$ & $\begin{array}{l}\text { A property has no mortgage } \\
\text { value where there is no } \\
\text { market }\end{array}$ & $18(30.5)$ & 8 (13.6) & $11(18.6)$ & $22(37.3)$ & $59(100)$ \\
\hline e & $\begin{array}{l}\text { Mortgage is an investment } \\
\text { and is shrouded with } \\
\text { uncertainty }\end{array}$ & $31(52.5)$ & $23(39.0)$ & $3(5.10)$ & $2(3.4)$ & $59(100)$ \\
\hline
\end{tabular}


at the open market value basis to prevent sharp practices. On the contrary, majority of the respondent firms (94.9\% and $91.5 \%)$ agreed that on no account must reinstatement value and indemnity value respectively be taken into consideration in mortgage valuation. This position is reinforced, as shown in the same table, by the outright rejection of the inclusion of insurance value in mortgage valuation report by substantial percentage of the respondents (59.3\%).

It is the contention of these respondent firms that insurance valuation is quite distinct from mortgage valuation and, would require a separate instruction from client for it to be considered necessary. This is not in conformity with the opinion of Aluko (2000) in the literature. But, nearly $40.7 \%$ of the respondent firms agreed that the insurance value should be included in the valuation. Perhaps, this accounts for why few of those firms (5.1\% and $8.5 \%)$ respectively believed that reinstatement and indemnity value are necessary in mortgage valuation. The reason adduced is that, in the event of any misfortune or unfortunate incident such as fire hazards during the loan repayment period, the lender should still be able to have access to adequate compensation for the loss to be suffered.

\subsection{Method(s) of valuation}

It is significant to note from Table 5 that while a greater proportion of the respondent firms $(67.8 \%)$ agreed that cost or contractor's approach is the most frequently employed in mortgage valuation practice, about $32.2 \%$ of the respondents disagreed with this view. The above corroborate the responses of the firms sampled in Table 6 where majority $(44.1 \%)$, preferred cost approach as against 16.9\% and $39.3 \%$ who opted for comparison method and investment method respectively, as the most appropriate for mortgage valuation.

This is contrary to the dominant view in the literature which sees investment or income capitalization method as the most appropriate for mortgage valuation. But, the respondents contend that the property market in the country is not well developed and, as such, there are no market data on which other methods could be based. Hence, it is not unlikely that the respondent firms are trying to over protect their clients' interests or, alternatively, their professional fees as, in these situations, as the cost approach is likely to return a higher figure of value than the other two methods. The reasons adduced may not be far from the truth, particularly, that $44.1 \%$ of the respondents, as indicated in Table 5, agreed that a property has no mortgage value where there is no market. This blind adoption of cost approach might have serious consequences on loan repayment or default, as the case may be.

\subsection{Sources of valuation instruction}

As shown in Table 7, 38.1\% while some of the respondent banks always rely on a panel of valuers retained by them while $35.7 \%$ of the

Table 6. Most appropriate method of mortgage valuation

\begin{tabular}{llll}
\hline Methods & $\begin{array}{l}\text { Relative } \\
\text { frequency }\end{array}$ & $\begin{array}{l}\text { Absolute } \\
\text { frequency }(\%)\end{array}$ & $\begin{array}{l}\text { Cumulative } \\
\text { frequency }(\%)\end{array}$ \\
\hline Comparison & 10 & 16.9 & 16.9 \\
Investment or income capitalization & 22 & 37.3 & 54.2 \\
Cost or contractor's & 26 & 44.1 & 98.3 \\
No response & 1 & 1.7 & 100.0 \\
Total & 59 & 100.0 & - \\
\hline
\end{tabular}

Source: Field Survey and Analysis (2004). 
Table 7. Sources of valuation instruction

\begin{tabular}{llll}
\hline Sources & $\begin{array}{l}\text { Relative } \\
\text { frequency }\end{array}$ & $\begin{array}{l}\text { Absolute } \\
\text { frequency (\%) }\end{array}$ & $\begin{array}{l}\text { Cumulative } \\
\text { frequency }(\%)\end{array}$ \\
\hline $\begin{array}{l}\text { Panel of valuers on bank retainership } \\
\text { Independent valuer from the list obtained from the }\end{array}$ & 16 & 38.1 & 38.1 \\
professional institution or regulatory body & 1 & 2.4 & 40.5 \\
Borrower's valuer & 15 & 35.7 & 76.2 \\
In - house valuers (staff) & 10 & 23.8 & 100.0 \\
Total & 42 & 100.0 & - \\
\hline
\end{tabular}

Source: Field Survey and Analysis (2004).

same sample of respondents made use of borrower's valuer in preparing mortgage valuation. Also, about $23.8 \%$ of the respondent banks have in-house valuers as staff charged with the responsibility of mortgage valuation assignments as against $2.4 \%$ of respondents who relied on any independent valuer as long as such is recognized to practice the profession in the country.

A cursory look at the above frequencies will reveal one common thread that linked all the responses together. That is, it may be difficult for valuers on bank's retainership, borrower's valuer, and in-house valuers who are employees of the bank and whose independence is questionable, to arrive at objective mortgage value. Perhaps, this may be an explanatory variable for the inaccuracies in mortgage valuations.

\subsection{Information contents of mortgage valuation reports}

Since, as revealed in the previous tables above, banks consider mortgage valuation before advancing loans, it is reasonable to examine whether the valuation reports usually address the needs of the lending institutions. To accomplish this, some information contents identified in the literature and indicated in Table 8 were ranked using variables such as (i) of very great importance, (2) of great importance, (3) of some importance and (4) of no importance. Table 8 shows at a glance the importance weighting of responses of the respondents es- tate surveying and valuation firms and lending institutions. The contents were later ranked using the mean and the relative importance index (RII) score for the factors. As shown in the Table 8 , while date of valuation, physical description of property, type of interest and basis of valuation were ranked $1^{\text {st }}, 2^{\text {nd }}, 2^{\text {nd }}$ and $3^{\text {rd }}$ respectively to the valuation firms relative to their mean values and RII values, opinion of value, type of interest, state of the economy and structural condition of property were ranked $1^{\text {st }}$, $2^{\text {nd }}, 2^{\text {nd }}$ and $4^{\text {th }}$ respectively by the lending institutions. Apart from the type of interest, the valuers are currently not satisfying the needs of the lenders. Also, the RII and mean values respectively for location, basis of valuation and opinion of value of both respondents are very close indicating their importance in valuation reports. Again, from the Table 8, while purpose of valuation and state of the economy are considered not important to valuers, the lending intuitions relied on them as they were ranked, using RII and mean values, as $6^{\text {th }}$ and $2^{\text {nd }}$ respectively. This shows that, currently, mortgage valuation reports are not meeting the demands of lending institutions.

\section{IMPLICATIONS OF THE CURRENT TREND IN PRACTICE}

This section presents the consequential effects of the findings on mortgage valuation practice on the lending institutions as well as the estate surveying and valuation firms in the country. 


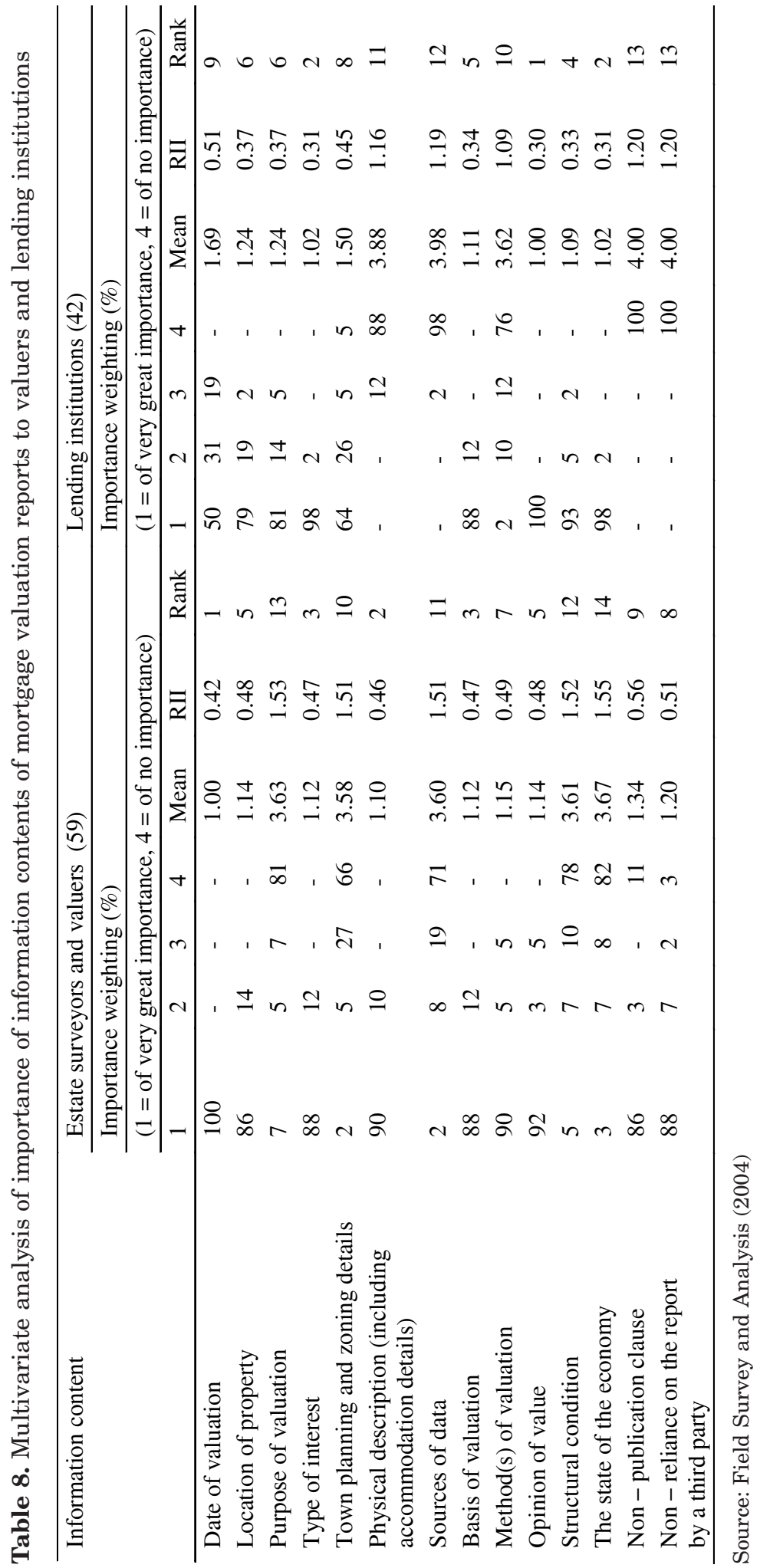


(i) Inappropriateness of the mortgage valuation: - The accuracy of any valuation depends on the adoption of appropriate pricing bases and methodology. While it is noted that open market value is being adopted in mortgage valuation, the current practice by some estate surveying and valuation firms at jettisoning the inclusion of forced sale value in their reports may make it impossible for the institutional lenders to evaluate the inherent risks associated with loan advances and the possibility of recoupment of the loan on the sale of the collateral security. Also, a few firms, contrary to the literature, adopt comparison and investment approaches to arrive at mortgage value and, majority only rely on cost or contractor's approach. This has serious implication on the mortgage valuation accuracy as it tends to over value collateral property in the market, as only the supply side is taken into consideration. The lending institution may, therefore, be misled into taking wrong decision since the security may not be adequate to liquidate the loan in case of default. It is reasonable to realize that mortgage is an investment both to the borrower and the institutional lender. Thus, investment value of the mortgaged property is important to the investors. And, in the event of default where the lender is to exercise power of sale or receivership, it is the capital value or rental value that would be achieved if the property were sold or let in the market. This can only be achieved through the assessment of investment value by either investment or comparison approach. The cost approach is only good to value properties that seldom change hands in the market. And, where a property has no demand in the market, it is reasonable to conclude that it cannot have mortgage value since it will not have investment value.

(ii) Abdication of professional responsibility:
- Furthermore, with the non-inclusion of insurance value of collateral property as opined by Aluko, (2000) and Mokrane, (2002), either on reinstatement or indemnity basis, in mortgage valuation as being currently practiced, it is reasonable to ask: what becomes of a lending institution if the collateral property is gutted by fire during the currency of the loan? This has to be positively looked into if the interest of both investors in the mortgage investment is to be adequately secured or protected through a mortgage valuation. To simply undertake a valuation without placing it into some economic, social and legal context is to abdicate professional responsibility. Therefore, it is the duty of professional valuers to explain the implication and extent of the valuation exercise to the client.

(iii) Conflicts of interest in mortgage valuation process: - The current practice of relying on mortgage valuation reports prepared by in-house staff valuers and panel valuation system through retainerships in lending decisions supports Manley (1993) and Hansz (2004) as explained above. This may help prevent fraud amongst lending institutions as collusion between the borrowers and valuer is less likely to arise. Nevertheless, conflicts of interest can still occur in both instances above as well as in the use of customers' valuers, which is equally rampant in loan underwriting process in the country. For instance, in-house staff valuers are employees of the bank and are, therefore, not independent. Banks may be able to influence the objectivity of staff valuers by promise of career prospects; and, in case of negligence or over-valuation, it may be difficult to sue them. The implication of this is that the valuation reports may be inaccurate and, by collusion between the lending institution and the staff valuers, borrowers could be defrauded. In the same vein, there could be strain on ob- 
jectivity where loss of panel status or retainership is used as a threat, particularly where the lending institution provides substantial source of instructions to the valuation firms. And, where a borrower's valuer is used, it is quite probable that the prospective borrower will shop around and send to the bank "cooked" or fraudulent valuation that suits his/her purpose. Perhaps, the use of independent valuers on the list provided by the professional association or regulatory body in country could help address the problems above.

(iv) Usefulness of the mortgage valuation reports to lending institutions: - Currently, mortgage valuations which are not meeting the needs of the institutional lenders may affect the credibility of the role and relevance of valuers in loan underwriting process. The banks may look elsewhere to satisfy their demands, although, this will mean others intruding into the domestic domain of valuers in the country. Thus, a mortgage valuation report must emphasize opinion of value, type of interest being valued, state of the economy as at the date of valuation and structural condition of collateral real property for it to meet demands of lending institutions. This has implication on the need for consistent standards in reporting as the investment borrowers and lenders alike need reliable comparable and consistent information concerning the status of mortgaged properties. The estate surveying and valuation profession cannot afford to assume that it will continue to be the dominant group in mortgage valuation practice. It must, therefore, adapt to changing requirements in the valuation reporting; moreso, that the performance measurement and analysis of any collateral property, non-transaction asset, is a function of the information contents in the valuation report.

\section{CONCLUSION}

The survey revealed that property valuation firms are not currently reflecting appropriate bases, methods and information contents in their mortgage valuations; also, the sources of valuation instruction are suspect and subject to conflicts of interest. The implications of this state of art of mortgage valuation practice were examined in the proceeding section. For example, most valuation firms only adopt open market valuation basis rather than, in addition to, forced sale valuation, in the valuation of collateral property. This approach does not allow for a margin of safety on the loan to value ratio to safeguard the interest of the lending institutions. Perhaps, with the demand for insurance policy on the collateral property and, a reflection of the insurance value of the collateral, the risks inherent in the mortgage valuations and loan underwriting process can be alleviated. Again, non - disclosure of the information required by mortgage valuation clients or the provision of information which the valuer knows or believes to be of no benefit to the client without comment to that effect may constitute abdication of professional responsibility and, as such, a breach of duty. If valuers are to provide the service expected of them, they must establish not only what the client requires but also who the client is and who, apart from the client, is likely to rely upon the report. Besides, the valuation firms are currently adopting, blindly, cost or contractor's method instead of investment and market comparison methods in mortgage valuations, which are recommended in the literature.

The foregoing has continued to result in mortgage valuation inaccuracies and often lead to sub - optimal lending decisions. As evident in the paper, this is one of the causes of banking distress currently being experienced in the country. The expertise of the estate surveyors and valuers in respect of mortgage valuations is, therefore, called into question. A number of the problems raised here could be addressed by both bankers and valuers through indi- 
vidual and joint institutional action and debate in the country. A joint professional standard committee needs to be set up by both The Nigerian Institution of Estate Surveyors and Valuers and the Chartered Institute of Bankers in the country. Perhaps through these efforts mortgage valuation standards, as internal regulatory mechanism, for valuers could emerge. Thus, through continuing professional development by way of workshops, seminars and conferences, valuers and lenders can be educated about the standards. This will greatly enhance the quality of mortgage valuations and, consequently, lending decisions based on them. It will, therefore, promote codification of good mortgage valuation practice in Nigeria. But, to allay the fears that standards would result to loss of independence to valuers and, that it will also represent an intrusion into private relationship between valuer and client, the new standards body must have the senior members of the two professions representing the various walks of professional life. Although, this in no way excludes academics, the preponderance must be men of successful practical experience.

Finally, lending institutions must ensure, for accuracy and objectivity purposes that independent valuers, neither retained by banks nor employed by borrowers but on the list of registered estate surveyors and valuers maintained by the Estate Surveyors and Valuers Registration Board of Nigeria (ESVARBON), are consulted to carry out mortgage valuations in the country. The Board is charged with the responsibility of regulating and controlling the property valuation practice in the country. With this, lending decisions will be based on sound, independent and objective valuations, the foundation of business and economic prosperity in the country.

\section{REFERENCES}

Adair, A., Downie, M. L., McGreal, S. and Vos., G. (1996) European Valuation Practice: Theory and Technique, E\&FN Spon, London.
Aluko, B. T. (1989) A Critical Examination of Valuation of Company Assets in Nigeria, an unpublished B.Sc. (Hons.) Dissertation, Department of Estate Management, Obafemi Awolowo University, Ile-Ife, Nigeria.

Aluko, B. T. (1993) An Empirical Study of Plant and Machinery Valuation Techniques in Lagos Metropolis, an unpublished M.Sc. Thesis, Obafemi Awolowo University, Ile-Ife, Nigeria.

Aluko, B. T. (1998) Property Valuation: Are Estate Surveyors and Valuers Interpreters or Creators of Value. The Estate Surveyor and Valuer, 2(2), July, p. 9-17.

Aluko, B. T. (2001) Relationship between Chieftaincy and Family Land in Ibokun, an unpublished LLB (Hons.) Thesis, Faculty of Law, University of Ibadan, Ibadan.

Aluko, B. T. (1999a) Mortgage Valuation, being a paper presented at an in-house seminar organized by Messrs Akintilo and colleagues, Lagos, $17^{\text {th }}$ July, $26 \mathrm{p}$.

Aluko B. T. (1999b) Valuation for Auction Sale Reserves and Receivership (Liquidation), being a paper presented at an in-house seminar organized by Messrs Akintilo and colleagues, Lagos, $17^{\text {th }}$ July, $13 \mathrm{p}$.

Aluko, B. T. (2000) A Study of the Appropriateness of Mortgage Valuation for Institutional Lending in Nigeria, an unpublished $\mathrm{PhD}$ Thesis, Obafemi Awolowo University, Ile-Ife, Nigeria.

Baum, A. E. (1986) The Valuation Profession in the 1990s. Estates Gazette, Vol. 271, p. 427-431.

Baum, A., Crosby, N., Gallimore, P., McAllister, P. and Gray, A. (2001) The Influence of Valuers and Valuations on the Workings of the Commercial Property Investment Market, Research Funded by the Education trusts of the Investment Property Four, Jones Lang Lansdale and the Royal Institution of Chartered Surveyors, London.

Baum, A. E., Mackmin, D. and Nunnington, N. (1997) The Income Approach to Property Valuation, International Thompson Business Press, London.

Cleary, E. J. (1965) The Building Society Movement, Elek, London.

Crosby, N. (1985) The Application of Equated Yield and Real Value Approaches to the Market Valuation of Commercial Property Investments, Unpublished PhD Thesis, University of Reading, Reading. 
Crosby, N. (1991) The Practice of Property Investment Appraisal: Reversionary Freeholds in the UK. Journal of Property Valuation and Investment, 9(2), p. 109-121.

Crosby, N., Newell, G., Matysiak, G., French, N. and Rodney, B. (1997) Client Perception of Property Investment Valuation Reports in the UK. Journal of Property Research, 14(1), p. 27-47.

Crosby, N., Lavers, A. and Foster, H. (2001) Commercial Property Loan Valuation in the UK: Implications of Current Trends in Practice and Liability, Draft Paper.

Elias, T. O. (1962) Nigerian Land Law and Custom, Routledge and Kegan Paul, London.

Gallimore, P. (1996) Editorial Comment. Journal of Property Valuation and Investment, 14(5), p. 4-6.

Gronow, S. (1992) Building Society Mortgage Valuation. Journal of Property Valuation and Investment, 10(4), p. 101-305.

Hansz, J. A. (2004) Prior Transaction Price Induced Smoothing: Testing and Calibrating the Quan Quigley Model at the Disaggregate Level. Journal of Property Research, 21(4), p. 321-336.

Hansz, J. A. and Diaz, J. (2001) Valuation Bias in Commercial Appraisal: A Transaction Price feedback Experiment. Real Estate Economics, 29(4), p. 553-565.

Lovell, R. and French, N. (1995) Estimated Realization Price: What do the banks want and what can realistically be provided? Journal of Property Valuation and Investment, 6(4), p. 7-16.

Manley, J. (1993) The Valuation of Commercial Property for Sale by Auction. Journal of Property Valuation and Investment, 11(1), p. 11-16.

Marchitelli, R. (1992) Rethinking the cost approach. The Appraisal Journal, LX(3), July, p. 424-426.

Mason, J. J. (1993) The Cost Approach. The Appraisal Journal, LXI(1), January, p. 116-128.

Millington, A. F. (1988) An Introduction to Property Valuation, The Estates Gazette Limited, London.

Mokrane, M. (2002) Valuation - Standards, Accuracy and Consistency, IPD European Property Strategy Conference, May.

NDIC (Nigeria Deposit Insurance Corporation). (1991-2003) Annual Reports and Statements of Accounts, NDIC, Lagos.
NIESV (Nigerian Institution of Estate Surveyors and Valuers). (1985) Property Valuation Standards, NIESV, Lagos.

NIESV. (1994-2003) Directories of Members, NIESV, Lagos.

Oetzel, T. R. (1993) Some Thoughts on the Cost Approach. The Appraisal Journal, LXI(1), January, p. 132-135.

Ogunba, O. A. and Ajayi, C. A. (1998) An Assessment of the Accuracy of Valuations in the Residential Property Market of Lagos. The Estate Surveyor and Valuer, 21(2), July, p. 19-23.

Ordway, N. and Bell, D. W. (1984) Can we teach appraisal better or can we teach better appraisal? The Appraisal Journal, July, p. 436-442.

Rees, W. H. (1988) ed., Valuation: Principles into Practice, $3^{\text {rd }}$ edition, The Estates Gazette Limited, London.

RICS (Royal Institution of Chartered Surveyors). (1990) Statements of Asset Valuation Practice and Guidance Notes, The Asset Valuation Standards Committee, RICS, London.

Rodgers, T. (1994) Property-to-property Comparison. The Appraisal Journal, LXII(1), January, p. 64-67.

Sachs, D. (1985) The Insurance Appraisal. The Appraisal Journal, April, p. 244-248.

Stork, H. and Humphries, C. (1996) Valuation for Loan Security, in Adair, A., Downie, M. L., McGreal, S. and Vos. G. (1996) ed., European Valuation Practice: Theory and Techniques, E\&FN Spon, London.

Tobi, N. (1992) Cases and Materials on Nigerian Land Law, $1^{\text {st }}$ Education, Mabrochi Books, Lagos.

Trott, A. (1980) Property Valuation Methods: Interim Report, Polytechnic of South Bank/Royal Institution of Chartered Surveyors, London.

Trott, A. (1986) Property Valuation Methods, Polytechnic of South Bank/Royal Institution of Chartered Surveyors, London.

Wood, E. (1972) Property Investment - A Real Value Approach, an unpublished PhD Thesis, University of Reading, Reading. 
SANTRAUKA

BŪSTO PASKOLŲ VERTINIMAS NIGERIJOJE: ESAMŲ TENDENCIJŲ PRASME்

\section{Bioye Tajudeen ALUKO}

Ši tyrimą paskatino didejantis rūpestis dẻl nekilnojamojo turto vertinimų variantiškumo bei tikslumo ir nuskurdusių Nigerijos bankų sukelti padariniai. Kadangi, priimant sprendimą suteikti paskolą, vertinti ją būtina, tyrimo išvados galbūt padètų ieškoti politinių sprendimų dèl nesuvaldomo bankų žlugimo šalyje. Todèl darbe nustatyta ir ištirta būsto paskolų vertinimo svarba, įskaitant vertinimo instrukcijų šaltinių, pagrindų ir taikomų metodų reikšmę, nagrinėtas būsto paskolų vertinimas, priimat sprendimus suteikti paskolą, ir vertintojo profesija šioje srityje. Anketomis ir pokalbių metu apklaustos 59 atsitiktine tvarka atrinktos turto tikrinimo bei vertinimo firmos (iš 146 aktyviai veikiančių; iš viso yra 239 tokio pobūdžio firmos) ir 42 skolinančios institucijos iš 89, veikiančių Lagose. Gauti duomenys išanalizuoti skaičiuojant pasiskirstymą, rangavimą ir santykinès svarbos indeksą. Tyrimu nustatyta, kad teikiamas paskolas vertinti yra svarbu. Tolesnè analizè parodé, kad į būsto paskolų vertinimą neįeina draudimo vertinimas, aklai pasirenkamas sąnaudų aspektas ir vertintojų nuomonès dèl būsto paskolų skiriasi. Tai, kas išdėstyta, skirta vertintojams, skolintojams arba kitiems vertinimo paslaugų vartotojams ir turto rinkai apskritai. 